\title{
STUDI FENOMENOLOGI: KUALITAS HIDUP PEREMPUAN DENGAN KANKER SERVIKS DALAM ASPEK KESEHATAN FISIK
}

\author{
Christiyanty $^{1}$, Wahyu Dewi Sulistyarini ${ }^{2}$, Yusnita Sirait ${ }^{3}$ \\ ${ }^{1}$ Program Studi IImu Keperawatan ITKES Wiyata Husada, JI. Kadrie Oening No. 77, \\ Samarinda, Kalimantan Timur. \\ Gmail : christiyantys10@gmail.com \\ ${ }^{2}$ Program Studi IImu Keperawatan ITKES Wiyata Husada, JI. Kadrie Oening No. 77, \\ Samarinda, Kalimantan Timur. \\ Gmail : wahyudewis@stikeswhs.ac.id \\ ${ }^{3}$ Praktisi Keperawatan RSUD Abdul Wahab Sjahranie Samarinda, JI. Palang Merah No. 1, \\ Sidodadi, Samarinda, Kalimantan Timur. \\ Gmail : chuanainggolan2015@gmail.com
}

\begin{abstract}
ABSTRAK
Latar belakang : Kanker serviks merupakan penyakit kanker yang terjadi pada leher rahim. Kanker serviks adalah kanker yang disebabkan oleh infeksi Human Papilloma Virus (HPV) yang terjadi di sel-sel serviks. Penderita kanker serviks yang sudah melakukan kemoterapi akan mengalami efek dari kemoterapi seperti mual, muntah, tidak nafsu makan, penurunan berat badan, dan alopesia. Hal ini mengakibatkan penderita kanker serviks mengalami perubahan dan menimbulkan berbagai keluhan secara fisik yang dapat mempengaruhi kualitas hidupnya.Tujuan: Mengeksplorasi pengalaman kualitas hidup perempuan dengan kanker serviks dalam aspek kesehatan fisik. Metode Penelitian : Penelitian ini menggunakan pendekatan fenomenologi dengan jumlah partisipan sebanyak 4 orang dengan kriteria yaitu : (1) perempuan dengan kanker serviks; (2) perempuan yang mampu berkomunikasi dengan baik, dibuktikan dengan menggunakan Mini-Mental State Exam (MMSE); (3) perempuan yang telah menyetujui sebagai partisipan dibuktikan dengan pengisian informed consent, sehingga partisipan tidak merasa terpaksa selama mengikuti proses kegiatan penelitian dan dipilih menggunakan teknik purposive sampling. Hasil : Terdapat 2 tema dari penelitian ini yaitu; (1) Penurunan fungsi fisiologis pada perempuan kanker serviks; (2) Nyeri kronik yang dialami perempuan kanker serviks. Kesimpulan : Perempuan kanker serviks mengalami penurunan fungsi fisiologis dan mengalami nyeri kronik selama menjalani pengobatan.
\end{abstract}

Kata kunci : kesehatan fisik, kualitas hidup, kanker serviks 


\section{PENDAHULUAN}

Kanker serviks merupakan penyakit kanker yang terjadi pada leher rahim. Kanker serviks adalah kanker yang disebabkan oleh infeksi Human Papilloma Virus (HPV) yang terjadi di sel-sel serviks. Sel-sel ini sendiri berkembang secara bertahap karena pengaruh zat-zat yang bersifat karsinogen (zat pemicu kanker) dan memakan waktu bertahun-tahun hingga menjadi sel prakanker $^{[17]}$.

Jumlah penderita kanker serviks tahun 2013 sebanyak 0,3\%, Provinsi Kepulauan Riau, Provinsi Maluku Utara dan Provinsi D.I Yogyakarta memiliki prevalensi kanker serviks tertinggi sebanyak $1,5 \%$ untuk di Kalimantan Timur berada diurutan 23 dari 34 Provinsi di Indonesia dengan angka kanker serviks sebesar $0,4 \%$ dengan jumlah 752 jiwa $^{[10]}$.

Gejala fisik kanker serviks pada umumnya dirasakan oleh penderita kanker serviks stadium lanjut, yaitu munculnya rasa sakit dan pendarahan saat berhubungan intim (contact bleeding), keputihan yang berlebihan dan tidak normal, perdarahan diluar siklus menstruasi, serta penurunan berat badan secara drastis ${ }^{[23]}$.

Penderita kanker serviks dengan stadium IB dan IIA dapat dilakukan terapi pembedahan, radiasi, dan kemoterapi. Penderita kanker serviks stadium IIB dan stadium lanjut dapat dilakukan terapi radiasi dan kemoterapi ${ }^{[19]}$. Penderita kanker serviks yang sudah melakukan kemoterapi akan mengalami efek dari kemoterapi seperti mual, muntah, tidak nafsu makan, penurunan berat badan, dan alopesia ${ }^{[19]}$. Hal ini mengakibatkan penderita kanker serviks mengalami perubahan dan menimbulkan berbagai keluhan secara fisik, psikologis, sosial, spiritual yang dapat mempengaruhi kualitas hidupnya ${ }^{[23]}$.

Kualitas hidup merupakan suatu persepsi individu terhadap kehidupannya di masyarakat dalam konteks budaya dan sistem nilai yang berhubungan dengan tujuan hidup dan target individu ${ }^{[6]}$. WHOQoL group pada tahun 2004 menyebutkan dimensi kualitas hidup terdiri dari 4 dimensi yaitu dimensi kesehatan fisik, kesehatan psikologis, hubungan sosial dan lingkungan. Maka peneliti tertarik untuk mengeksplorasi kualitas hidup perempuan dengan kanker serviks dalam aspek kesehatan fisik ${ }^{[23]}$.

\section{METODE}

Penelitian ini menggunakan purposive sampling. Purposive sampling adalah teknik penetapan sampling yang dapat sesuai dengan kriteria yang peneliti harapkan, sehingga sampel tersebut dapat mewakili karakteristik populasi dari yang dikenal sebelumnya $^{[13]}$. Pemilihan partisipan menggunakan metode criterion sampling ${ }^{[15]}$. Adapun kriteria informan dalam penelitian ini sebagai berikut: (1) perempuan dengan kanker serviks; (2) perempuan yang mampu berkomunikasi dengan baik, dibuktikan dengan menggunakan Mini-Mental State 
Jurnal Keperawatan Wiyata

Volume 2, Nomor 1, Tahun 2021

ISSN 2774-4558 (Cetak)

ISSN 2774-9789 (Online)

Halaman 91-100

Exam (MMSE) digunakan sebagai alat untuk mendeteksi adanya gangguan kognitif pada seseorang/individu, mengevaluasi perjalanan suatu penyakit yang berhubungan dengan proses penurunan kognitif dan memonitor respon (Turana, 2004); (3) perempuan yang telah menyetujui sebagai partisipan dibuktikan dengan pengisian informed consent, sehingga partisipan tidak merasa terpaksa selama mengikuti proses kegiatan penelitian.

\section{HASIL}

Ada dua tema yang di peroleh dari beberapa kategori yang ditemukan melalui proses koding. Tema yang diperoleh menggambarkan pengalaman kualitas hidup partisipan kanker serviks dalam aspek kesehatan fisik. Tema diperoleh melalui proses analisis pada unit analisis, juga didengarkan berulang dan secara rinci agar peneliti mendapatkan makna yang menjadi dasar pembentukan kategori, kemudian kategori yang ada di kelompokkan pada tema, tema yang di peroleh peneliti yaitu: (1) penurunan fungsi fisiologis pada perempuan kanker serviks; (2) nyeri kronik yang dialami perempuan kanker serviks.

\section{PEMBAHASAN}

\section{Penurunan fungsi fisiologis pada perempuan kanker serviks}

Penurunan fungsi fisiologis pada perempuan kanker serviks terjadi pada beberapa aspek diantaranya perubahan integumen, disfungsi motilitas gastrointestinal, intoleransi aktivitas dan gangguan kebutuhan istirahat. $\mathrm{Hal}$ ini dimungkinkan karena perempuan kanker serviks mengalami penurunan cara kerja dari fungsi fisiologis pada tubuhnya dan mengakibatkan sistem integumen seperti rambut ataupun kulit mengalami perubahan karena pengaruh dari kemoterapi yang dijalani.

Pasien kanker yang menjalani kemoterapi dan kemoterapi radioterapi mengalami perubahan pada kulit seperti pigmentasi kulit, pruritus, eritema acral/palmar-plantar eritrodisestesi (PPE), xerosis dan perubahan pada rambut seperti alopecia. Sehingga efek kemoterapi mengakibatkan penurunan fungsi fisiologis perempuan kanker serviks terutama pada perubahan sistem integumennya ${ }^{[12]}$.

Perubahan integumen pada perempuan kanker serviks terdiri dari perubahan rambut rontok dan kulit menghitam. Hal ini dimungkinkan rambut rontok dan kulit menghitam merupakan efek dari kemoterapi.

Kerontokan rambut yang disebabkan kemoterapi diduga sebagai akibat dari penghentian aktivitas mitosis pada matriks rambut yang mengakibatkan bagian batang rambut menjadi sempit dan melemah. Obat yang digunakan untuk kemoterapi dan efeknya rambut menjadi rontok seperti kombinasi siklofosfamid dan doksorubisin, paclitaxel dan carboplatin, cyclophosphamide, doxorubicin dan vincristine, vincristine dan daunorubicin, cisplatin, carboplatin, dan kombinasi cisplatin 
Jurnal Keperawatan Wiyata

Volume 2, Nomor 1, Tahun 2021

ISSN 2774-4558 (Cetak)

ISSN 2774-9789 (Online)

Halaman 91-100

dan 5 FU. Perempuan kanker serviks bisa

mengalami rambut rontok dikarenakan obat kemoterapi yang masuk ke dalam tubuh ${ }^{[18]}$. Efek samping merupakan hal yang pasti didapati pasien kanker pada saat kemoterapi. Kemoterapi akan mengakibatkan perubahan fisik seperti kulit menghitam dan kelelahan. Selain kerontokan rambut efek dari kemoterapi bisa menyebabkan kulit menghitam ${ }^{[20]}$. Sehingga kemoterapi yang terjadi pada perempuan kanker serviks mengakibatkan perubahan integumen yang terdiri dari rambut rontok dan kulit menghitam.

Selain terjadi perubahan pada integumen perempuan dengan kanker serviks juga akan mengalami perubahan disfungsi motilitas gastrointestinal. Disfungsi motilitas gastrointestinal merupakan peningkatan, penurunan, tidak efektif atau kurangnya aktivitas peristaltik gastrointestinal ${ }^{[16]}$. Disfungsi yang terjadi pada sistem gastrointestinal antara lain penurunan berat badan, penurunan nafsu makan, mual dan muntah, muntah. Penurunan berat badan terjadi pada saat perempuan menjalani kemoterapi kemudian mengalami mual dan muntah. Hal itu yang mengakibatkan perempuan akan mengalami penurunan nafsu makan dan tidak berminat pada makanan.

Penurunan berat badan yang mulai terjadi saat pasien mendapatkan terapi kemoterapi dan penurunan berat badan terjadi secara bertahap. Salah satu faktor penyebab penurunan berat badan adalah intake nutrisi yang kurang. Penurunan berat badan bisa terjadi karena beberapa faktor di antaranya adalah penurunan nafsu makan yang disebabkan oleh mual, muntah, dan mukositis yang dialami oleh penderita kanker serviks dengan kemoterapi. Respons fisik berupa mual dan muntah munculnya bervariasi yaitu pada saat selama pemberian kemoterapi, setiap lima menit, setengah sampai 2 jam setelah pemberian kemoterapi dan bahkan mual dan muntah dapat terjadi sehari, dua dan tiga hari setelah pemberian kemoterapi. Sensasi yang dirasakan ada mual atau mual dan muntah. Munculnya gejala mual dan muntah ada yang hilang timbul dan terus menerus. Respons mual dan muntah diklasifikasikan menjadi akut, terlambat, dan antisipatif. Akut terjadi kurang dari 24 jam setelah kemoterapi, terlambat terjadi 24 jam atau lebih setelah kemoterapi. Muntah dapat diinduksi oleh berbagai zat kimia, obat sitostatik dan yang diperantai melalui Chemoreceptors Trigger Zone (CTZ). CTZ berlokasi di medulla yang berperan sebagai chemosensor. Area ini kaya akan berbagai reseptor neurotransmitter. Contoh dari reseptor-reseptor tersebut antara lain reseptor kolinergik dan histamin, dopaminergik, opiate, serotonin, neurokinin dan benzodiazepine. Terjadinya mual dan muntah akan mengakibatkan penurunan nafsu makan. Respons fisik berupa penurunan nafsu makan setelah menjalani kemoterapi dan bahkan tidak mau makan 
Jurnal Keperawatan Wiyata

Volume 2, Nomor 1, Tahun 2021

ISSN 2774-4558 (Cetak)

ISSN 2774-9789 (Online)

Halaman 91-100

sama sekali selama pemberian kemoterapi

serta frekuensi makan yang menjadi tidak teratur ${ }^{[1]}$.Sehingga perempuan kanker serviks yang menjalani kemoterapi akan mengalami disfungsi motilitas gastrointestinal seperti penurunan berat badan, penurunan nafsu makan, mual dan muntah.

Efek lain yang dirasakan perempuan kanker serviks akan mengalami intoleransi aktivitas. Intoleransi aktivitas merupakan ketidakcukupan energi psikologis atau fisiologis untuk mempertahankan atau menyelesaikan aktivitas kehidupan seharihari yang harus atau yang ingin dilakukan ${ }^{[5]}$. Intoleransi aktivitas yang terjadi perempuan kanker serviks akan mengalami seperti kelelahan baik secara operatif, pasca kemoterapi, keletihan, dan merasa lemah.

Respon fisik berupa kelelahan (fatigue) dapat terjadi 1 sampai 2 minggu setelah pemberian kemoterapi. Kelelahan (fatigue) muncul saat berjalan dan melakukan kegiatan rumah tangga seperti menyapu, mencuci dan memasak. Gejala fisik yang dirasakan meliputi perasaan lelah, capek, rasa tidak kuat, sesak napas. Kelelahan dapat terjadi karena kebutuhan nutrisi yang kurang sehingga kebutuhan energi dalam tubuh tidak tercukupi. Kelelahan dapat muncul beberapa hari setelah pengobatan kemoterapi dan akan terus akan semakin memburuk. Pengobatan kemoterapi akan mengakibatkan kelelahan yang akan dialami perempuan kanker serviks ${ }^{[1]}$. Kelelahan pasca operasi muncul sebagai perasaan tidak enak dan distress yang dipengaruhi oleh gejala subjektif dan perilaku. Perasaan ini mungkin membuat pasien enggan untuk bergerak pada periode pasca operasi ${ }^{[14]}$. Kelelahan perempuan kanker serviks dirasakan setelah dilakukan tindakan operasi.

Efek samping penyakit kanker dan kemoterapi dirasakan pasien dimana pasien mengeluh keletihan sebagai perasaan lemah, mudah lelah dan kehilangan tenaga atau kemampuan berkonsentrasi. Keletihan ini akan terus dirasakan perempuan kanker serviks sebagai efek dari kemoterapi ${ }^{[7]}$. Sehingga efek dari kemoterapi akan mengakibatkan intoleransi aktivitas seperti kelelahan operatif , kelelahan pasca kemoterapi, keletihan dan merasa lemah.

Perempuan kanker serviks juga akan mengalami gangguan kebutuhan istirahat. Gangguan kebutuhan istirahat seperti nocturia, insomnia dan deprivasi tidur. Deprivasi tidur merupakan periode waktu panjang tanpa berhentinya kesadaran relatif periodik dan berlangsung alami untuk istirahat ${ }^{[5]}$.

Efek samping dari kemoterapi mengakibatkan pasien kanker stadium lanjut merasakan kelemahan yang lebih besar, kelelahan, dan keterbatasan fisik dibandingkan pasien lain, mereka lebih banyak mengeluh gejala nokturia. Pada pasien NCl-CTC grade II / III, kandung kemih menjadi kaku atau berkontraksi sehingga mengarah pada perkembangan gejala seperti nokturia dan mengejan saat buang air kecil ${ }^{[2]}$. 
Jurnal Keperawatan Wiyata

Volume 2, Nomor 1, Tahun 2021

ISSN 2774-4558 (Cetak)

ISSN 2774-9789 (Online)

Halaman 91-100

Pasien kanker serviks akan merasakan gambaran nyeri mereka seperti nyeri teriris

kelahan dan mengalami nocturia akibat efek dan tertusuk. Region of pain merupakan dari kemoterapi. Insomnia dan gangguan lokasi keluhan nyeri yang dirasakan dimana tidur yang lain merupakan salah satu region of pain ini biasanya akan merasakan masalah yang paling banyak terjadi pada pasien kanker selain nyeri, anoreksia, kelelahan, dan merasa lemas. Gangguan tidur seperti insomnia dan kurang tidur merupakan efek dari pengobatan yang dijalani pasien kanker ${ }^{[9]}$. Sehingga gangguan kebutuhan istirahat seperti nocturia, insomnia dan deprivasi tidur menjadi masalah yang dirasakan perempuan kanker serviks akibat efek dari pengobatan.

Nyeri kronik yang dialami perempuan kanker serviks

Nyeri kronik yang dialami perempuan kanker serviks menggambarkan tiga hal utama dalam pengkajian nyeri yang terdiri dari provocative of pain, quality of pain dan region of pain. Provocative of pain merupakan penyebab timbulnya nyeri yang bisa dikarenakan terkena ruda paksa, benturan, penyayatan dan hal lainnya. Pada perempuan kanker serviks biasanya akan menjalani tindakan invasif. Tindakan invasif merupakan tindakan medis yang dapat mempengaruhi keutuhan jaringan tubuh pasien dimana tindakan invasif ini akan memicu munculnya nyeri akibat dari radiasi dan post operatif. Quality of pain merupakan ukuran dalam menentukan berat keluhan nyeri dan lamanya nyeri yang dirasakan. Perempuan kanker serviks yang merasakan nyeri akan memberikan penjelasan nyeri viseral. Nyeri viseral merupakan nyeri yang berasal dari orgam dalam sukar untuk dilokalisasi dan bisa menyebar ke tempat lain seperti nyeri di bagian vagina, pelvic, suprapubik dan tulang. Nyeri kronik merupakan pengalaman sensorik atau emosional yang berkaitan dengan kerusakan jaringan aktual atau fungsional dengan onset mendadak atau lambat dan berintensitas ringan hingga berat dan konstan yang berlangsung lebih dari 3 bulan $^{[16]}$. Hal ini dimungkinkan nyeri kronik yang dirasakan perempuan kanker serviks disebabkan oleh efek pengobatan kemoterapi.

Tingkat nyeri pasien yang sedang menjalani kemoterapi lebih cenderung pada tingkat sedang dan berat, hanya sebagian kecil pasien yang mengalami nyeri ringan. Hal ini dikarenakan pasien dengan kanker akan mengalami nyeri kronik yang menetap dengan rangkaian program tindakan yang akan dilakukan ${ }^{[8]}$. Sehingga perempuan kanker serviks akan mengalami nyeri kronik yang disebabkan oleh efek dari kemoterapi.

Provocative of pain perempuan kanker serviks diakibatkan karena tindakan invasif. Tindakan invasif yang dijalani antara lain nyeri radiasi dan nyeri post operatif. mengalami berbagai efek samping salah satunya nyeri yang disebabkan karena tindakan invasif. 
Jurnal Keperawatan Wiyata

Volume 2, Nomor 1, Tahun 2021

ISSN 2774-4558 (Cetak)

ISSN 2774-9789 (Online)

Halaman 91-100

Penyebab nyeri setelah pengobatan

perempuan kanker serviks seperti nyeri teriris

kanker ada banyak dimana rasa sakit dapat dan nyeri tertusuk merupakan efek dari berkembang setelah kemoterapi (diinduksi kemoterapi neuropati perifer), radioterapi, pembedahan (persisten nyeri pascaoperasi), terapi hormon, atau transplantasi sel induk ${ }^{[3]}$. Sehingga perempuan kanker serviks yang telah menjalani tindakan invasif berupa radioterapi dan pasca operasi akan merasakan nyeri.

Selain provocative of pain pengkajian nyeri lainnya adalah quality of pain. Quality of pain perempuan kanker serviks biasanya mereka akan menjelaskan gambaran nyeri yang mereka merasakan. Gambaran nyeri yang terjadi setelah menjalani pengobatan seperti nyeri teriris dan nyeri tertusuk.

Nyeri adalah masalah utama bagi kebanyakan pasien kanker serviks selama mereka menjalani prosedur pengobatan. Pasien kanker serviks mengalami nyeri secara fisik dan emosional dimana mereka mengatakan nyeri yang hebat dan menggambarkan nyeri seperti terpotong menggunakan pisau tajam. Nyeri yang pasien kanker serviks alami digambarkan seperti nyeri terpotong ataupun teriris ${ }^{[4]}$. Gejala nyeri neuropatik pada pasien kanker seperti nyeri spontan (terbakar, meremas, dan tekanan), nyeri paroksismal (sengatan listrik dan sensasi menusuk), nyeri yang ditimbulkan seperti dengan menyikat, menekan, atau menyentuh dan disesthesia /paresthesia

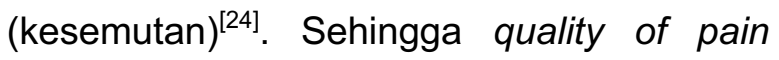
berupa gambaran nyeri yang dirasakan pengobatan.

Region of pain pada perempuan kanker serviks terjadi karena adanya kerusakan jaringan yang nyata di dalam tubuh yang akan dirasakan perempuan kanker serviks salah satunya nyeri viseral. Perempuan kanker serviks akan merasakan nyeri viseral antara lain nyeri vagina, nyeri pelvic, nyeri suprapubik dan nyeri tulang.

Pasien kanker serviks mengatakan nyeri yang dirasakan terlokalisir di daerah sekitar rahim dan pelvis. Nyeri pasien kanker serviks dirasakan pada daerah panggul atau dimulai dari ekstremitas bagian bawah dari daerah lumbal dan pada stadium lanjut kemungkinan nyeri yang dirasakan dapat bervariasi. Pasien kanker serviks juga mengatakan bahwa nyeri yang dirasakan menyebar ke daerah paha ${ }^{[11]}$. Keluhan yang sering di keluhkan pasien kanker adalah sulit buang air kecil dan nyeri tulang. Keluhan ini terjadi pada saat pasien kanker sudah berada pada tahap lanjut ${ }^{[21]}$. Sehingga region of pain perempuan kanker serviks akan merasakan nyeri viseral di bagian pelvic dikarenakan kanker yang sudah bermetastase dan efek dari pengobatan.

\section{KESIMPULAN}

Berdasarkan hasil penelitian perempuan kanker serviks mengalami penurunan fungsi fisiologis dan mengalami nyeri kronik selama menjalani pengobatan.

\section{REFERENSI}


Jurnal Keperawatan Wiyata

Volume 2, Nomor 1, Tahun 2021

ISSN 2774-4558 (Cetak)

ISSN 2774-9789 (Online)

Halaman 91-100

1. Ambarwati, W. N., \& Wardani, E. K. 7. Kolin, M. Y. K., Warjiman, \& Mahdalena. (2015). Respons dan koping pasien penderita kanker servik terhadap efek kemoterapi. Jurnal Ners, 10(1), 48-60.

2. Cho, O. H., Yoo, Y. S., Kim, J. C., Park, R. H., \& Hwang, K. H. (2018). Factors influencing lower urinary tract symptoms in advanced cancer patients with chemotherapy-induced peripheral neuropathy. International Neurourology Journal, 22(3), 192-199. https://doi.org/10.5213/inj.1836084.04

3. Doo, A. R., Shin, Y. S., Yoo, S., \& Park, J. K. (2018). Radiation-induced neuropathic pain successfully treated with systemic lidocaine administration. Journal of Pain Research, 11, 545-548. https://doi.org/10.2147/JPR.S155070

4. Dzaka, A., \& Maree, J. (2016). Experiences of women receiving high dose rate brachytherapy for cervical cancer at an academic hospital. Southern African Journal of Gynaecological Oncology, 8(2), 42-45. https://doi.org/10.1080/20742835.2016.1 257174

5. Heardman, T Heather. (2018). NANDA-I Diagnosis Keperawatan Definisi dan Klasifikasi 2018-2020.Jakarta: ECG.

6. Karimi, M., \& Brazier, J. (2016). Health, Health-Related Quality of Life, and Quality of Life: What is the Difference? PharmacoEconomics, 34(7), 645-649. https://doi.org/10.1007/s40273-0160389-9 (2016). Kualitas hidup pasien kanker yang menjalani kemoterapi tahun 2014. Jurnal Stikes Suaka Insan Banjarmasin, 1(1), 69-74. https://journal.stikessuakainsan.ac.id/ind ex.php/jksi/article/download/21/12

8. Laely, A. (2016). Pengaruh Hipnotherapi Terhadap Penurunan Tingkat Nyeri dan Kecemasan Pada Pasien Kemoterapi di RS Dr. Kariadi. Journal of Clicinal Medicine,

https://doi.org/10.36408/mhjcm.v4i1.247

9. McGinty, H.L., Carroll, A.J., Sanford, S.D. (2017). Sleep Disturbance in Cancer Survivors. In Hrayr P. A, Current Clinical Neurology : Clinical Handbook of Insomnia 3rd Ed. Switzerland: Springer International Publishing, hal. 221- 242.

10. Ministry of Health Indonesia. (2015). Pusat Data dan Informasi Kementrian Kesehatan Republik Indonesia, InfoDatin "STOP KANKER" Ministry of Health Indonesia. https://doi.org/2442-7659

11. Natosba, J., Rahmania, E. N., \& Lestari, S. A. (2019). Studi Deskriptif: Pengaruh Progressive Muscle Relaxation Dan Hypnotherapy Terhadap Nyeri Dan Kecemasan Pasien Kanker Serviks Descriptive Study: the Effect of Progressive Muscle Relaxation and Hypnotherapy on Pain and Anxiety of Cervical Cancer Patients.

12. Naveed, S., Thappa, M. D., Dubashi, B., Pandjatcaram, J., Munisamy, M., \& 
Jurnal Keperawatan Wiyata

Volume 2, Nomor 1, Tahun 2021

ISSN 2774-4558 (Cetak)

ISSN 2774-9789 (Online)

Halaman 91-100

Singh, N. (2019). Mucocutaneous 19. Savitri, A., Larasati, \& E.K.D, U. (2015).

Adverse Reactions of Cancer Kupas Tuntas Kanker Payudara, Leher

Chemotherapy and Chemoradiation.

Indian Journal of Dermatology, 64(2),

Rahim, dan Rahim (1st ed.). Pustaka

122-128. https://doi.org/10.4103/ijd.IJD

$\underline{12917}$

13. Nursalam. (2015). Metodologi Penelitian IImu Keperawatan Pendekatan Praktis (P. P. Lestari (ed.); 4th ed.). Salemba Medika.

14. Oliveira, M. M. De, Oliveira, G. F. De, Souza-talarico, J. N. De, Delalibera, D., \& Faria, C. De. (2016). Surgical Oncology: Evolution of Postoperative Fatigue and Factors Related to Its Severity. 20(1), 3-8.

15. Patton, MQ. (2001). Qualitative Research and Evaluation Methods (2nd Edition). Thousand oaks, CA:Sage Publications.https://www.qualres.org/Ho meSamp-3702.html

16. PPNI, T. P. S. D. (2016). Standar Diagnosis Keperawatan Indonesia Definisi dan Indikator Diagnostik. Dewan Pengurus Pusat Persatuan Perawat Nasional Indonesia.

17. Riksani, R. (2016). Kenali Kanker Serviks Sejak Dini (Maya (ed.); I). Rapha Publishing.

18. Saraswat, N., Chopra, A., Sood, A., Kamboj, P., \& Kumar, S. (2019). Topical Ciclopirox Olamine 1\%: Revisiting a Unique Antifungal. Indian Dermatology Online Journal, 10(4), 481-485. https://doi.org/10.4103/idoj.IDOJ 
Jurnal Keperawatan Wiyata

Volume 2, Nomor 1, Tahun 2021

ISSN 2774-4558 (Cetak)

ISSN 2774-9789 (Online)

Halaman 91-100 